\title{
THE POSSIBILITY OF GRIZZLY BEARS STILL EXISTING IN SASKATCHEWAN
}

\author{
by Thomas White, Regina
}

The Grizzly Bear or Grizzly was thought to have been extirpated from Saskatchewan before the turn of the century, but there now appears to be a possibility that a small remnant may remain. I have found it of interest to collect historical references to the former existence of this bear within or adjacent to the province and to relate stories of persons who claim to have seen them recently.

The Grizzly was named by George Ord of Philadelphia in 1815 following descriptions given by Lewis and Clarke after their expedition along the Missouri River to the Pacific Coast. Their experiences of its ferocity prompted Ord to give it the scientific name Ursa horribilis. The widespread publicity given the Lewis and Clarke expedition made the existence of this bear well known, but it is interesting to note that it had already been described for over a century by many British explorers in Canada and that the term "grizzly bear" was in current use at that time. Later, the Grizzly became subject to controversy; the Plains Grizzly, which is larger, has been considered by some a subspecies, Ursa horribilis horribilis, while others believe that it may be a separate species. The Grizzlies of southern Saskatchewan were believed to be of the Plains Grizzly type, and this identification is supported by a number of skulls in the National Museum in Ottawa. Whether all Saskatchewan Grizzlies were Plains Grizzlies is unknown.

In early historical times the Grizzly ranged over large areas of western North America, from Mexico to the Arctic. It was subsequently extirpated over much of its earlier range, just as the buffalo was, by the settlers and ranchers. The most recent survey of the Grizzly in North America, which is a preliminary study by Victor $\mathrm{H}$. Calahane (1964), shows that the vast majority of the remaining Grizzlies are in the western mountains north of the 49th parallel, though there are a few in Yellowstone and Glacier $\mathrm{Na}$ tional Parks, and in small pockets as far south as Mexico. In Canada,
Grizzlies are numerous in British Columbia, Alberta, and the Yukon, and they are increasing in the Northwest Territories. The nearest of these known locations is several hundred miles from the Saskatchewan border, and it would therefore be of considerable interest should a remnant be found within the province. It should also be noted that a few years ago a population of Plairis Grizzly was discovered north of Edmonton in the Swan Hills of Alberta. As the Plains Grizzly previously was considered extinct, this discovery was of considerable interest.

\section{Early records of Grizzlies in Saskatchewan and adjacent regions}

In 1690 Henry Kelsey was sent by the Hudson Bay Company from its post at the Bay on a voyage of exploration to the Canadian prairies, and as such he was the first known white man to see the Canadian section of the great plains. His journals contain references to many animals which he saw and there is a strong tradition that he killed two Grizzlies, for which the Indians named him "Little Giant." There are references in his journal Doughty and Martin (1929) to these bears. An entry for September, 1690 refers to "an outgrown bear which is good meat" whose hide the Indians discouraged him from keeping because "they said it was God", and on August 20, 1691 Kelsey wrote:

"Today we pitcht to ye outtermost Edge of ye woods this plain affords nothing but short Round sticky grass \& Buffillo \& a great (sort) or of a Bear wch is Bigger than any white Bear \& is Neither White nor Black But silver hair'd like our English Rabbit, ye Buffillo Likewise is not like those to ye Northward their Horns growing like an English $\mathrm{Ox}$ but Black."

Kelsey was therefore the first white man to describe the Grizzly and to kill one, though his diary was not published for many years after, in 1929. The white bear to which he 


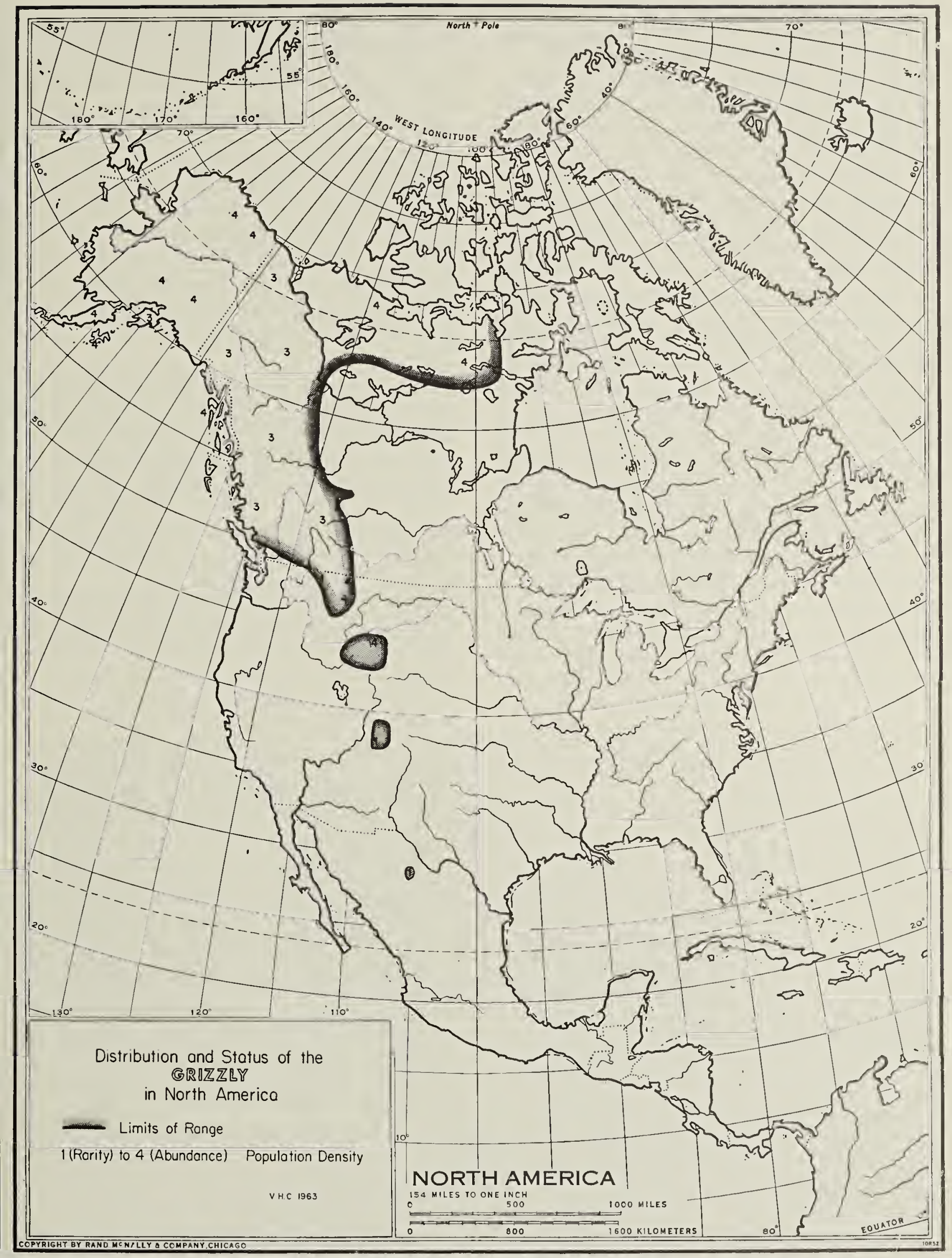

Map from Cahalane (1964) showing the distribution and status of the Grizzly in North America, based on a preliminary study sponsored by the New York Zoological Society and the Boone and Crockett Club. 
alludes is the Polar Bear of Hudson Bay where he started his epic journey.

In 1754 William Henday (or Hendry) was travelling in the area south of the North Saskatchewan River near the Alberta border when one of his men was killed by a grizzly and another was attacked (Burpee, 1907). Edward Umpreville, when wintering at Cumberland House in 1784, reports Grizzly on the Saskatchewan River and states that many Indians were maimed (Wallace, 1954). Sir Alexander Mackenzie on his first crossing to the Pacific, having passed through Saskatchewan, found them on the Peace River in 1793 (Sheppe, 1962). Grizzlies were apparently not uncommon in the area to the south of Brandon, and probably extending as far as Moose Mountain and southern Saskatchewan, e.g., Alexander Henry (Coues, 1897 ) in 1800 has reports of Grizzly skins being taken from the Pembina Mountains, Pembina River, Portage la Prairie, Salt River, Devil's Lake, Cheyenne River and Reed River. He describes the local distribution as varying from "not numerous along the Red River" to "very numerous and dangerous" at the Cheyenne River. It would seem that between 1800 and 1805 there was a considerable number of these bears in this general area. In 1808 Alexander Henry (Coues, 1897) wrote that Grizzlies were common in the Nipawin area, which is on the Saskatchewan River within 50 miles of the Pasquia Hills. Sir John Richardson (1829) saw one killed at Carlton House in 1820 and said that their range extended from the Rocky Mountains to latitude $61^{\circ}$ on the Saskatchewan. The Palliser Expedition (1863) came upon two at the Elbow of the Saskatchewan River in 1865 and succeeded in killing the smaller one, which was 92" long and had a head 16" broad. Isaac Cowie, who carried out a survey over several years (1867$1874)$, writes (1913) that there were incredible numbers of Grizzlies in the Cypress Hills and that the Indians did not hunt there owing to their fear of them. In the summer of 1872, 750 skins were taken out of the Cypress Hills at Chimney Coulee. The Fort Pelly journals (Klaus, 1961) report skins being turned over in considerable numbers in 1857 and more came when the carts from Fort Qu'Appelle, Fort Ellis and the Touchwood Hills arrived. In the 1880's there were horses still bearing claw marks from Grizzly attacks in the Cypress Hills, according to Corky Jones (pers. commun.) and at the same time they were still being killed in the Eagle Hills south of Battleford, according to an Indian interviewed by R. D. Symons (pers. commun.). In the 1890's Grizzlies were killed in the sand hills north of Maple Creek; and, according to Steve Mann (pers. commun.) there is a story of one being lassoed in the Cypress Hills at the turn of the century. It would seem that there are no records after this date, and so the Grizzly has been written off as extirpated from the province.

In addition to these recorded occurrences, Grizzly skulls found near Shaunavon and Maple Creek are deposited in the National Museum in Ottawa. Two other skulls are exhibited in a museum in Maple Creek, and another skull, found near Prince Albert, is exhibited in Lund's Wildlife Exhibit in that city.

One undated reference attributed to Ernest Thompson Seton (MacFarlane, 1908) mentions Grizzlies occasionally being found in the Pas Mountains of Cumberland House and the Touchwood Hills of Manitoba. The "Pas Mountains" of which Seton speaks are the Pasquia Hills and Wapaweeka Hills in Saskatchewan, and it is in this area that rumours of Grizzlies have persisted.

The Pasquia Hills and Wapaweeka Hills are one of the roughest and wildest parts of the province and are very thickly wooded. At the Red Earth Hudson Bay Post, Mr. Hutton, the son of the factor, says there are stories of Grizzly skins being handed in before the First World War. Stanley Holloway, who laid out the trails for The Pas Lumber Company, says bears have been shot, the skins of which cover a barn door and which were known as Grizzlies. The Indians in that area have a separate name for a large bear which is said to live in the Pasquia Hills; it is supposed to be different than a Black Bear and has a reputation of being fierce. Sixty years ago, according to Joe Fournier (a resident of the area and a trappernaturalist) a Saulteaux Indian was killed by a bear in the area; on another occasion an Indian who is still living at Red Earth was maimed by a bear. Even today there is a taboo 
in this area of the Pasquia Hills, and Indians will not enter the area unless they are in a large group and well armed. There are persistent rumours among Indians, trappers, loggers, and woodsmen of great cinnamon-colored bears in the Nipawin area being slain from time to time.

Ansgar Aschim, a forester and at this writing President of the Saskatchewan Natural History Society, while flying over the Porcupine Hills in 1960 saw a very large bear with a high hump on its back and a large nose, which Aschim is certain was a Grizzly (pers. corres.) The helicopter pilot, who was used to flying over the Swan Hills of Alberta where he had been accustomed to seeing Grizzlies, was also sure it was a Grizzly. As the helicopter was only 100 feet over the bear and both observers had a clear view, this sighting under perfect conditions by experienced woodsmen has real value.

In the mid 1950's, Joe Fournier is certain he found a Grizzly in the east portion of the Pasquia Hills. According to his story, he was approaching a ravine when he saw a large animal on the other side which he first thought was a moose. As he drew near he saw that it was a huge bear which did not walk like a Black Bear and which had a different shape and profile. It moved off when he tried to track it. When he reached the place where the bear had been, he found the foot prints were over a foot in length and three to four inches in depth in dry earth.

In the wilder parts of the Pasquia Hills there is a high area called Wildcat Hill, near which is a fire tower and hut. I have been told that some years ago a local towerman was besieged in the hut for a number of days by a large bear which came every evening and tried to force its way in. The towerman finally escaped by leaving some food outside of the hut and running towards Shoal Lake Indian Reserve. The size of the bear, its apparent intention toward the towerman, and its daily visits are unusual for the normal Black Bear.

On the May 24th weekend, 1964, I organized an expedition to the Pasquia Hills, consisting of members of the Regina Natural History Society,

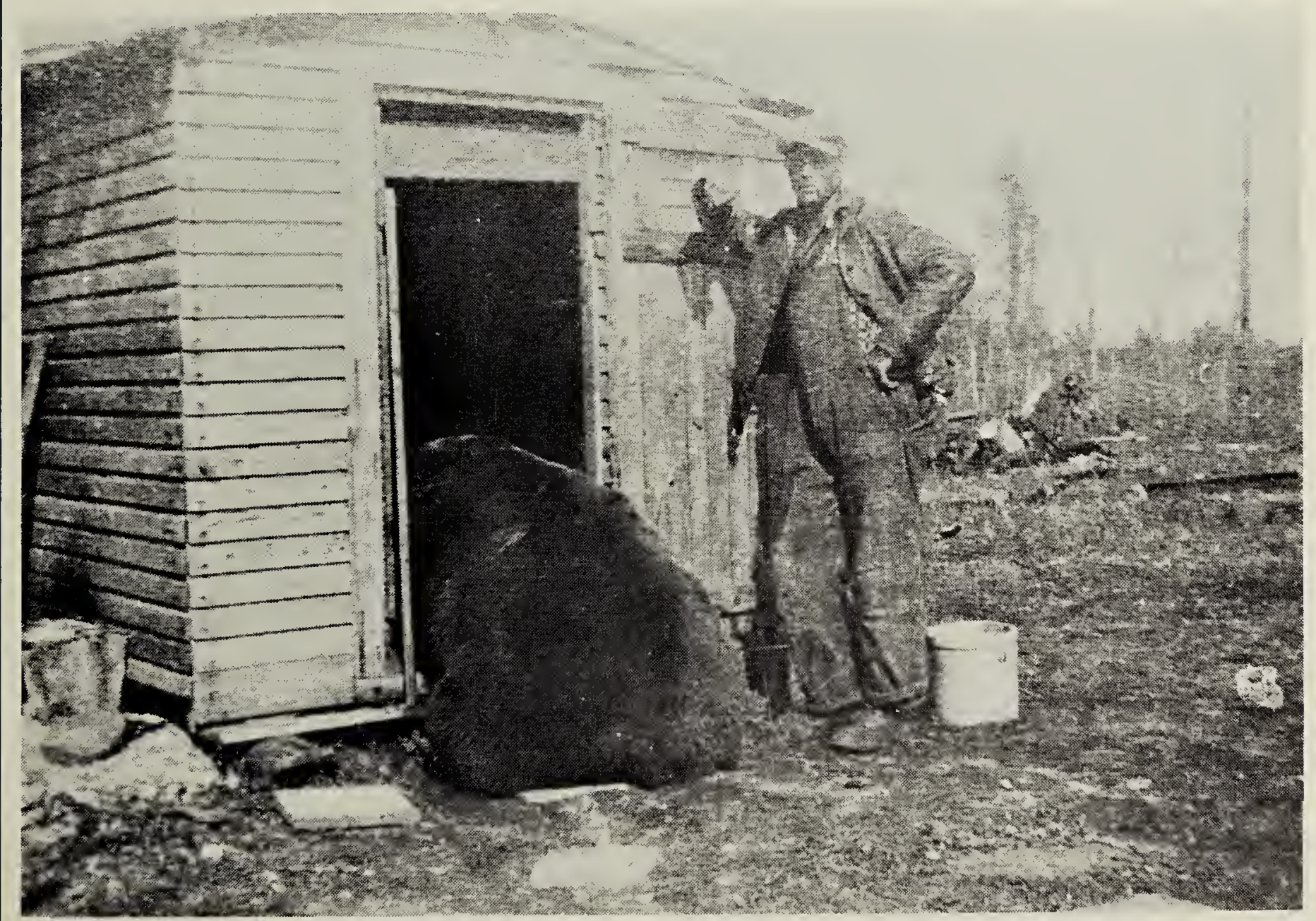

Bear killed by set-gun in 1939 at Veillardville, possibly a Grizzly 
to search for information about Cougars and Grizzlies. The Conservation Officer at Carrot River, Mr. J. G. Cockwill, remembered an unusual bear which had been shot by a Mr. Gerry Murdock in 1939. I was able to obtain photographs of this bear and these were submitted to Dr. Philip M. Youngman, Curator of Mammals at the National Museum of Canada at Ottawa. Dr. Youngman states (pers. corres., 1964) that, judging by the photograph, the bear shot by $\mathrm{Mr}$. Murdock was almost certainly a Grizzly. The story of the bear shot by Mr. Murdock is thus of interest: while he was homesteading to the south of the Pasquia Hills at Veillardville. a giant bear broke into the home, drank a five gallon crock of cream and caused much damage. The Murdocks were in terror of their lives and so stayed with neighbors. A gun was left on a trip wire behind the door of the storage shed, and when the bear opened the door it was shot between the eyes and died immediately (see photograph).

In the summer of 1964 Ansgar Aschim landed on an esker, which is a ridge formed during the ice age, in northwestern Saskatchewan north of the Clearwater River trying to locate a fire tower. He came upon many signs which he took to be of Grizzly. There were very large footprints and trails along the crest of the esker with all of the branches on nearby trees broken off to a five foot height. Droppings found on the esker were not Black Bear type. There were lakes on both sides of the esker with well-worn trails leading down to them, which suggests that these bears were doing some fishing.

All stories of large and exceptional bears seen in the woods have to be carefully appraised and considered, since mistakes and unintentional exaggerations are common. Any naturalist can give examples of reports which when checked do not conform to the details supplied. On the other hand, it is an historical fact that Grizzlies were widely distributed in Saskatchewan and that they occurred up to the 1890 's in considerable numbers. There are historical references to Grizzlies in the Nipawin area and Pasquia Hills region. I have heard of many other stories of Grizzlies, but those mentioned above are largely from trained and experienced woodsmen.
Since the bear shot in 1939 was described by a professional mammalogist as 'almost certainly a Grizzly, the other stories seem more credible. The wilder parts of the Pasquia Hills have been little known for there have been no roads into the Hills until recently. This is probably the only area in central Saskatchewan where a small population of Grizzly could remain undetected. In the northern part of the province there are large uninhabited areas where other populations might still exist. This bear has long been written off as extirpated from Saskatchewan, but there would seem to be a definite possibility that a few still remain alive. As it was in Saskatchewan that the Grizzly was first described, and as so many of the early explorers who first described it have Saskatchewan connections, it would form a valuable link with the past if it could be shown that a few of these great bears still remain in our province.

\section{LITERATURE CITED}

Burpee, L. J. (Editor). 1907. The journal of Anthony Hendry, 1754-55. Proc. and Trans. Royal Soc. Canad., 3rd Series, Vol. 1, p.307359. James Hope and Son, Ottawa.

Cahalane, V. H. 1964. A preliminary study of distribution and numbers of cougar, grizzly and wolf in North America. New York Zoological Society, New York. 12 p.

Cowie, I. 1913. The company of adventurers. William Briggs, Toronto. $515 \mathrm{p}$.

Coues, E. (Editor). 1897. The manuscript journals of Alexander Henry and of David Thompson. 3 vols. Francis R. Harper, New York. $1027 \mathrm{p}$.

Doughty, A. G., and C. Martin. 1929. The Kelsey papers. The Public Archives of Canada and the Public Record Office of Northern Ireland. Queen's Printer, Ottawa. $128 \mathrm{p}$.

Klaus, J. F. 1961. Fort Pelly: an historical sketch. Saskatchewan History, Vol. 14. The Saskatchewan Archives Board, Saskatoon.

MacFarlane, R. R. 1908. Notes on the mammals and birds of northern Canada. (And, Through the Mackenzie Basin ... by Charles Mair). William Briggs, Toronto. 494 p.

Palliser, J. 1863. The journals, detailed reports, and observations relative to the exploration, by Captain Palliser, of that portion of British North America... during the years 1857, 1858, 1859, and 1860. Eyre and Spottiswoode, London. 325 p.

Richardson, J. 1829. Fauna Boreali Americana. Vol. 1. John Murray, London. 300 p.

Sheppe, W. 1962. First man west, Alexander Mackenzie's account of his expedition across North America to the Pacific in 1793. Univ. Calif. Press, Berkeley and Los Angeles. 366 p.

Wallace, W. S. (Editor). 1954. Present state of Hudson's Bay... (Journals of Edward Umfreville, first published in 1790). Ryerson Press, Toronto. 122 p. 